\title{
Effect of Professional and Extra-Professional Exposure on Seroprevalence of SARS-CoV-2 Infection among Healthcare Workers of the French Alps: A Multicentric Cross-Sectional Study
}

\author{
Virginie Vitrat ${ }^{1, *(\mathbb{D}}$, Alexis Maillard ${ }^{2}{ }^{-}$, Alain Raybaud ${ }^{3}$, Chloé Wackenheim ${ }^{4}$, Bruno Chanzy ${ }^{5}$, Sophie Nguyen ${ }^{6}$, \\ Amélie Valran ${ }^{1}$, Alexie Bosch ${ }^{7}$, Marion Noret ${ }^{2}$ and Tristan Delory ${ }^{2}$ (D) \\ 1 Infectious Diseases Department, Annecy Genevois Hospital, 74370 Epagny Metz-Tessy, France; \\ avalran@ch-annecygenevois.fr \\ 2 Clinical Research Unit, Annecy Genevois Hospital, 74370 Epagny Metz-Tessy, France; \\ maillard.alexis@laposte.net (A.M.); mnoret@ch-annecygenevois.fr (M.N.); \\ tdelory@ch-annecygenevois.fr (T.D.) \\ 3 Occupational Medicine Department, Alpes Leman Hospital, 74130 Contamine sur Arves, France; \\ araybaud@ch-alpes-leman.fr \\ check for \\ updates \\ Citation: Vitrat, V.; Maillard, A.; \\ Raybaud, A.; Wackenheim, C.; \\ Chanzy, B.; Nguyen, S.; Valran, A.; \\ Bosch, A.; Noret, M.; Delory, T. Effect \\ of Professional and Extra-Professional \\ 4 Infectious Diseases Department, Alpes Leman Hospital, 74130 Contamine sur Arves, France; \\ cwackenheim@ch-alpes-leman.fr \\ 5 Virology Laboratory, Annecy Genevois Hospital, 74370 Epagny Metz-Tessy, France; \\ bchanzy@ch-annecygenevois.fr \\ 6 Hygiene Unit, Annecy Genevois Hospital, 74370 Epagny Metz-Tessy, France; snguyen@ch-annecygenevois.fr \\ 7 Infectious Diseases Department, Metropole Savoie Hospital, 73000 Chambery, France; \\ alexie.bosch@ch-metropole-savoie.fr \\ * Correspondence: vvitrat@ch-annecygenevois.fr; Tel.: +33-4-56-63-66-19; Fax: +33-4-56-63-64-42
} Exposure on Seroprevalence of SARS-CoV-2 Infection among Healthcare Workers of the French Alps: A Multicentric Cross-Sectional Study. Vaccines 2021, 9, 824. https:// doi.org/10.3390/vaccines 9080824

Academic Editors: Angelos Hatzakis, Ralph J. DiClemente and

Dimitrios Paraskevis

Received: 10 May 2021

Accepted: 22 July 2021

Published: 27 July 2021

Publisher's Note: MDPI stays neutral with regard to jurisdictional claims in published maps and institutional affiliations.

Copyright: (c) 2021 by the authors. Licensee MDPI, Basel, Switzerland. This article is an open access article distributed under the terms and conditions of the Creative Commons Attribution (CC BY) license (https:/ / creativecommons.org/licenses/by/ $4.0 /)$.
Abstract: We aimed to report SARS-CoV-2 seroprevalence after the first wave of the pandemic among healthcare workers, and to explore factors associated with an increased infection rate. We conducted a multicentric cross-sectional survey from 27 June to 31 September 2020. For this survey, we enrolled 3454 voluntary healthcare workers across four participating hospitals, of which $83.4 \%$ were female, with a median age of 40.6 years old (31.8-50.3). We serologically screened the employees for SARS-CoV-2, estimated the prevalence of infection, and conducted binomial logistic regression with random effect on participating hospitals to investigate associations. We estimated the prevalence of SARS-CoV-2 infection at 5.0\% (95 CI, 4.3\%-5.8\%). We found the lowest prevalence in health professional management support (4.3\%) staff. Infections were more frequent in young professionals below 30 years old (aOR $=1.59$, (95 CI, 1.06-2.37)), including paramedical students and residents $(\mathrm{aOR}=3.38,(95 \mathrm{CI}, 1.62-7.05))$. In this group, SARS-CoV-2 prevalence was up $16.9 \%$. The location of work and patient-facing role were not associated with increased infections. Employees reporting contacts with COVID-19 patients without adequate protective equipment had a higher rate of infection ( $\mathrm{aOR}=1.66$, (95 CI, 1.12-2.44)). Aerosol-generating tasks were associated with a 1.7 -fold rate of infection, regardless of the uptake of FFP2. Those exposed to clusters of infected colleagues $(\mathrm{aOR}=1.77,(95 \mathrm{CI}, 1.24-2.53))$ or intra-familial COVID-19 relatives $(\mathrm{aOR}=2.09,(95 \mathrm{CI}, 1.15-3.80))$ also had a higher likelihood of infection. This report highlights that a sustained availability of personal protective equipment limits the SARS-CoV-2 infection rate to what is measured in the general population. It also pinpoints the need for dedicated hygiene training among young professionals, justifies the systematic eviction of infected personnel, and stresses the need for interventions to increase vaccination coverage among any healthcare workers.

Keywords: COVID-19; SARS-CoV-2; healthcare workers; cross-sectional survey; serologic testing 


\section{Introduction}

The global prevalence of SARS-CoV-2 infection was reported higher in healthcare workers than in the general population, at $8.7 \%$ (CI 95, 6.7\% to 10.9\%) [1,2]. It ranged from 0 to $45.3 \%$, depending on the country, continent, and studies, and was around $8.5 \%$ in Europe [2].

In France, during the first wave, the national strategy was to detect symptomatic incident infections by reverse transcriptase polymerase chain reaction (RT-PCR). Yet, the prevalence of the infection, including asymptomatic forms, in French healthcare workers remains poorly known. In small-sized studies, it was ranging from $2.2 \%$ in serologic screening among asymptomatic healthcare workers to $28 \%$ in RT-PCR among symptomatic healthcare workers [3-5].

Demographics, patient-facing roles, and tests used for serologic testing can influence the estimation of infection prevalence [1,2]. In the general population, the uptake of personal protective equipment was shown to reduce virus transmission, but the effect of the type of occupation, protective equipment shortages, and hospital organization on the risk of infection is debated $[2,6]$.

In this report, we aimed to estimate the seroprevalence of SARS-CoV-2 infection after the first wave of the pandemic among healthcare workers of the French Alps, and to explore if the infection rate varied by subgroups of care workers, types of occupation, hospital organization, or the uptake of protective equipment.

\section{Materials and Methods}

\subsection{Study Context, Design, and Population}

We conducted a multicentric cross-sectional study among four of the five public hospitals of the French Alps (NCT04845984). It was based on data issued from the mass serologic campaign initiated by the French Ministry of Health after the first wave of the pandemic, conducted at the national level among healthcare workers. The first wave of the pandemic ended at the time of the lockdown release on 11 May. According to national guidelines, from 27 June to 31 September 2020, any volunteer healthcare institution employees could reach the occupational medicine unit to be screened for SARS-CoV-2 infection by serology testing. Medical and nursing students were also invited to be screened. Before the serology testing, we invited the participants to fill out a self-questionnaire about (1) their demographics, (2) type and place of occupation, (3) being in a patientfacing role, (4) exposure to COVID-19 cases at work and in private life, (5) the use of personal protective equipment, and (6) symptoms of COVID-19. The self-questionnaire is available in Appendix A. We did not collect repeated data. At the beginning of the survey (27 June 2020), the daily incidence among the general population in the surveyed area was ranging from 0 to 0.2 per 100,000 inhabitants. At the end of the survey (31 September 2020), it increased to 8.3-32 per 100,000 inhabitants. The second national lockdown started on 29 October at a daily incidence of 163.5 to 203.7 per 100,000 inhabitants.

\subsection{Serology Testing}

The SARS-CoV-2 serology testing was done using the commercial test kits available in each participating hospital. Hospital 1 used the Abbott Architect SARS-CoV-2 IgG assay, Abbott Laboratories, Maidenhead, UK (IgG Sensitivity $=100 \%$, IgG Specificity $=99.6 \%$ ), the others used the Roche Elecsys Anti-SARS-CoV-2, Roche Diagnostics International Ltd, Rotkreuz, Switzerland (total antibody) assay (Pan IgG Sensitivity $=100 \%$, Pan IgG Specificity $=99.8 \%$ ). Sensibility and specificity are reported according to the EUA Authorized Serology Test Performance [7].

\subsection{Healthcare Worker Classification}

We classified healthcare workers according to the 2008 version of the International Standard Classification of Occupations (ISCO) [8]: (1) health professionals, (2) health 
associate professionals, (3) personal care workers in health services, (4) health management and support personnel, and (5) health service provider not elsewhere classified.

\subsection{Sample Size}

We enrolled 3454 healthcare workers, a sample that provided $84 \%$ power at a $5 \%$ bilateral first species risk (alpha) to detect a $4.4 \%$ (CI 95, 2.8\% to 6.5\%) prevalence of infection, as measured in the general population in the survey area after the first wave [9].

\subsection{Statistical Analysis}

We computed the frequencies and percentages for discrete variables and the median and interquartile range (IQR) for continuous variables. We used the chi-squared test to compare rates. We measured the prevalence of SARS-CoV-2 infection and its 95\% confidence interval (CI 95) as the number of healthcare workers with positive serology testing over the number of tested personnel during the study. Because of the hospital effect, we used binomial logistic regressions with random effect (clustering) on the hospital to investigate the strength of associations between the presence of an infection in healthcare workers (outcome) and the variables included in the multivariable regression. The unit of analysis was the individual. Variables included in the multivariable regression were defined a priori, and no automatic variable selection was performed: age, sex, healthcare worker occupation according to the ISCO, student status, patient-facing role, professional exposure to SARS-CoV-2 (working in a COVID-19 unit, performing an aerosol-generating task, cases among colleagues), uptake of personal protective equipment, working in an emergency ward, working remotely full-time, and contact with intra- and extra-familial cases. Associations are reported as the odds ratio (OR) and their CI 95. All tests were two-tailed, and the level of significance was set at 5\% bilateral. Analyses were performed on $\mathrm{R}$, version 4.0.1 (R Foundation for Statistical Computing, Vienna, Austria), using the 'glmmML' and 'ggplot2' packages.

\subsection{Patient and Public Involvement}

No patients were involved in setting the research questions or the outcome measures, nor were they involved in developing plans for the study design. No patients were asked for advice on the interpretation or the writing up of the results.

\section{Results}

\subsection{Characteristics of Respondents}

We enrolled 3454 staff members across four hospitals, corresponding to a $28.3 \%$ participation rate, and to $77.6 \%$ of professionals who underwent serology testing (Figure 1). In Hospital 3, the serologic screening was only proposed in a few wards, and $8.5 \%$ of the personnel were tested for serology. In others, $50.4 \%$ to $62.5 \%$ of healthcare workers were screened. According to the ISCO, 1818 (52.6\%) of staff members were healthcare professionals, $766(22.2 \%)$ were health-associated professionals, $854(24.7 \%)$ were health management and support personals, and $16(0.5 \%)$ did not report their occupation. Workers had a median age of 40.6 years old (31.8-50.3), 83.4\% were female, and 631 had performed RT-PCR before the study, of which $13.3 \%$ were positive. Table 1 details the staff members' characteristics overall and by hospital.
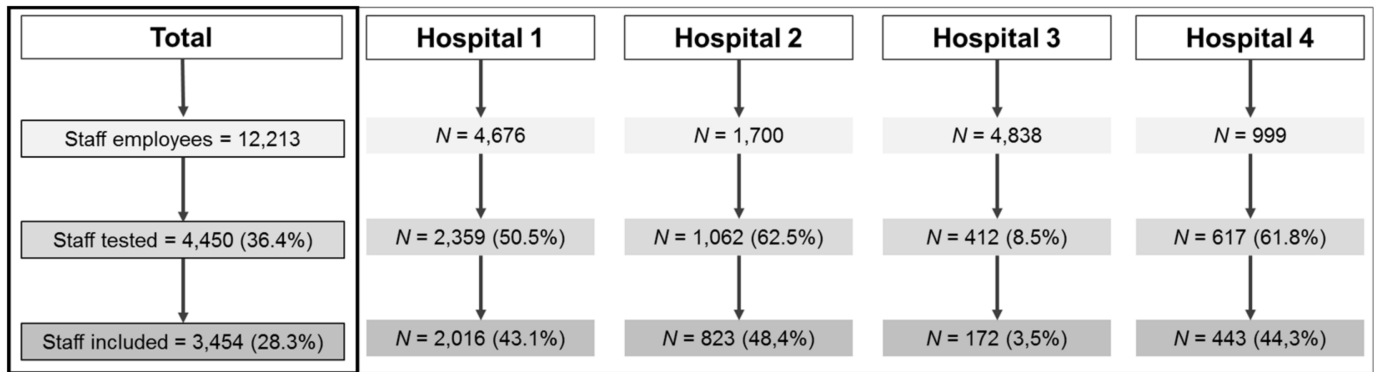

Figure 1. Flowchart of participant enrolment. 
Table 1. Characteristics of healthcare workers, overall and by participating hospital.

\begin{tabular}{|c|c|c|c|c|c|c|}
\hline \multirow{2}{*}{$\begin{array}{l}\text { Healthcare Worker } \\
\text { Characteristics }\end{array}$} & \multirow{2}{*}{ Missing (\%) } & \multirow{2}{*}{$\begin{array}{c}\text { Overall } \\
N=3454\end{array}$} & \multirow{2}{*}{$\begin{array}{c}\text { Hospital } 1 \\
N=2016\end{array}$} & \multirow{2}{*}{$\begin{array}{c}\text { Hospital } 2 \\
N=823\end{array}$} & \multirow{2}{*}{$\begin{array}{c}\text { Hospital } 3 \\
N=172\end{array}$} & \multirow{2}{*}{$\begin{array}{c}\text { Hospital } 4 \\
N=443\end{array}$} \\
\hline & & & & & & \\
\hline Demographics & & $\begin{array}{l}N(\%) \text { or Med } \\
\quad(I Q R)\end{array}$ & $\begin{array}{l}N(\%) \text { or Med } \\
\quad(I Q R)\end{array}$ & $\begin{array}{c}N(\%) \text { or Med } \\
(I Q R)\end{array}$ & $\begin{array}{c}N(\%) \text { or Med } \\
(I Q R)\end{array}$ & $\begin{array}{c}N(\%) \text { or Med } \\
\text { (IQR) }\end{array}$ \\
\hline $\begin{array}{l}\text { Age, continuous } \\
\text { (years) }\end{array}$ & $2.2 \%$ & $40.6(31.8,50.3)$ & $40.2(31.8,49.2)$ & $\begin{array}{l}41.2(32.0 \\
51.2)\end{array}$ & $\begin{array}{l}40.3(32.6 \\
50.9)\end{array}$ & $\begin{array}{l}41.8(31.3 \\
51.4)\end{array}$ \\
\hline Sex, female & $0.0 \%$ & $2880(83.4)$ & 1667 (82.7) & $683(83.1)$ & $145(84.3)$ & $385(86.9)$ \\
\hline $\begin{array}{l}\text { BMI, continuous } \\
(\mathrm{kg} / \mathrm{m} 2)\end{array}$ & $6.0 \%$ & $22.6(20.4,25.1)$ & $22.3(20.3,24.7)$ & $\begin{array}{l}23.2(20.8 \\
26.0)\end{array}$ & $\begin{array}{l}22.7(20.8 \\
24.7)\end{array}$ & $\begin{array}{l}22.5(20.2 \\
25.2)\end{array}$ \\
\hline Children at home & $10.2 \%$ & $1695(54.6)$ & $1031(56.6)$ & $396(53.7)$ & $80(51.0)$ & $188(48.3)$ \\
\hline $\begin{array}{c}\text { Household, }>1 \\
\text { inhabitant }\end{array}$ & $0.0 \%$ & $2078(60.2)$ & $1232(61.1)$ & $499(60.6)$ & $100(58.1)$ & $247(55.8)$ \\
\hline $\begin{array}{c}\text { Occupation } \\
\text { according to ISCO }+\end{array}$ & $0.5 \%$ & & & & & \\
\hline $\begin{array}{l}\text { Health management } \\
\text { and support } \\
\text { personnel }\end{array}$ & & $854(24.7)$ & $482(23.9)$ & $225(27.3)$ & $30(17.4)$ & $117(26.4)$ \\
\hline $\begin{array}{l}\text { Health associate } \\
\text { professionals }\end{array}$ & & $766(22.2)$ & 442 (21.9) & $170(20.7)$ & $49(28.5)$ & $105(23.7)$ \\
\hline Health professionals & & $1818(52.6)$ & $1080(53.6)$ & $425(51.6)$ & $93(54.1)$ & $220(49.7)$ \\
\hline Missing data & & $16(0.5)$ & $12(0.6)$ & $3(0.4)$ & $0(0.0)$ & $1(0.2)$ \\
\hline $\begin{array}{c}\text { Extra-professional } \\
\text { exposure }\end{array}$ & & & & & & \\
\hline $\begin{array}{l}\text { Intra-familial } \\
\text { confirmed cases }\end{array}$ & $0.0 \%$ & $175(5.1)$ & $96(4.8)$ & $41(5.0)$ & $11(6.4)$ & $27(6.1)$ \\
\hline $\begin{array}{l}\text { Extra-familial } \\
\text { confirmed cases } \\
\text { Professional } \\
\text { exposure }\end{array}$ & $0.1 \%$ & $185(5.4)$ & $107(5.3)$ & $39(4.8)$ & $18(10.5)$ & $21(4.7)$ \\
\hline $\begin{array}{l}\text { Working in } \\
\text { emergency ward }\end{array}$ & $0.1 \%$ & $282(8.2)$ & $151(7.5)$ & $57(6.9)$ & $0(0.0)$ & $74(16.7)$ \\
\hline $\begin{array}{l}\text { Working in } \\
\text { COVID-19 unit }\end{array}$ & $2.7 \%$ & & & & & \\
\hline Never & & $1496(44.5)$ & $885(45.3)$ & $380(47.4)$ & $81(47.1)$ & $150(34.6)$ \\
\hline Sometimes & & $749(22.3)$ & $465(23.8)$ & $175(21.8)$ & $12(7.0)$ & $97(22.4)$ \\
\hline Often & & $382(11.4)$ & 209 (10.7) & $90(11.2)$ & $12(7.0)$ & $71(16.4)$ \\
\hline Always & & $734(21.8)$ & $396(20.3)$ & $156(19.5)$ & $67(39.0)$ & $115(26.6)$ \\
\hline Working in & & & & & & \\
\hline $\begin{array}{l}\text { COVID-19 intensive } \\
\text { care unit }\end{array}$ & $2.8 \%$ & $134(4.0)$ & $71(3.6)$ & $30(3.8)$ & 27 (15.7) & $6(1.4)$ \\
\hline $\begin{array}{l}\text { Working in } \\
\text { COVID-19 room }\end{array}$ & $2.8 \%$ & $1730(51.5)$ & $999(51.1)$ & $390(48.8)$ & $64(37.2)$ & $277(64.0)$ \\
\hline Contact with & & & & & & \\
\hline $\begin{array}{l}\text { COVID-19 patients } \\
\text { without PPE } \ddagger\end{array}$ & $3.9 \%$ & $866(26.1)$ & $458(23.9)$ & $200(25.2)$ & $30(17.4)$ & $178(41.3)$ \\
\hline $\begin{array}{l}\text { Cluster of cases } \\
\text { among the team }\end{array}$ & $0.1 \%$ & 1102 (31.9) & $578(28.7)$ & $245(29.8)$ & $67(39.0)$ & $212(48.1)$ \\
\hline $\begin{array}{l}\text { Cluster of cases } \\
\text { among patients }\end{array}$ & $0.0 \%$ & $283(8.2)$ & $188(9.3)$ & $50(6.1)$ & $6(3.5)$ & $39(8.8)$ \\
\hline $\begin{array}{c}\text { Performed } \\
\text { aerosol-generating } \\
\text { tasks }\end{array}$ & $2.4 \%$ & 1033 (30.7) & $616(31.5)$ & $221(27.5)$ & $70(41.2)$ & $126(28.6)$ \\
\hline
\end{tabular}


Table 1. Cont.

\begin{tabular}{|c|c|c|c|c|c|c|}
\hline \multirow{2}{*}{$\begin{array}{c}\text { Healthcare Worker } \\
\text { Characteristics }\end{array}$} & \multirow{2}{*}{ Missing (\%) } & Overall & Hospital 1 & Hospital 2 & Hospital 3 & Hospital 4 \\
\hline & & $N=3454$ & $N=2016$ & $N=823$ & $N=172$ & $N=443$ \\
\hline Demographics & & $\begin{array}{c}N(\%) \text { or Med } \\
(I Q R)\end{array}$ & $\begin{array}{c}N(\%) \text { or Med } \\
(I Q R)\end{array}$ & $\begin{array}{c}N(\%) \text { or Med } \\
(I Q R)\end{array}$ & $\begin{array}{c}N(\%) \text { or Med } \\
(I Q R)\end{array}$ & $\begin{array}{c}N(\%) \text { or Med } \\
(I Q R)\end{array}$ \\
\hline $\begin{array}{l}\text { N95/FFP2 mask } \\
\text { during aerosol } \\
\text { generating-tasks }\end{array}$ & $2.6 \%$ & & & & & \\
\hline Not applicable & & 2337 (69.5) & $1341(68.6)$ & $582(72.8)$ & $100(58.8)$ & $314(71.7)$ \\
\hline Never & & $82(2.4)$ & $54(2.8)$ & $21(2.6)$ & $2(1.2)$ & $5(1.1)$ \\
\hline Sometimes & & $107(3.2)$ & $59(3.0)$ & $32(4.0)$ & $2(1.2)$ & $14(3.2)$ \\
\hline Often & & $261(7.8)$ & $158(8.1)$ & $61(7.6)$ & $11(6.5)$ & $31(7.1)$ \\
\hline Always & & $576(17.1)$ & $343(17.5)$ & $104(13.0)$ & $55(32.4)$ & $74(16.9)$ \\
\hline $\begin{array}{l}\text { Systematic wear of } \\
\text { surgical face mask } \\
\text { SARS-CoV-2 } \\
\text { infection }\end{array}$ & $0.0 \%$ & 2715 (78.6) & $1601(79.4)$ & $612(74.4)$ & $163(94.8)$ & $339(76.5)$ \\
\hline $\begin{array}{c}\text { Seroprevalence of } \\
\text { COVID-19 }\end{array}$ & $0.0 \%$ & $173(5.0)$ & $66(3.3)$ & $53(6.4)$ & $8(4.7)$ & $46(10.4)$ \\
\hline $\begin{array}{l}\text { Reporting symptoms } \\
\text { compatible with } \\
\text { COVID-19 }\end{array}$ & $0.0 \%$ & $2254(65.3)$ & $1346(66.8)$ & $493(59.9)$ & $98(57.0)$ & 317 (71.6) \\
\hline $\begin{array}{c}\text { Time between } \\
\text { symptoms and } \\
\text { serological screening }\end{array}$ & $34.8 \%$ & & & & & \\
\hline$\leq 14$ days & & $104(4.6)$ & $61(4.5)$ & $20(4.1)$ & $13(13.4)$ & $10(3.2)$ \\
\hline 15-29 days & & $194(8.6)$ & $112(8.3)$ & $36(7.3)$ & $21(21.6)$ & $25(7.9)$ \\
\hline$\geq 30$ days & & $1857(82.5)$ & $1102(82.0)$ & $423(85.8)$ & $62(63.9)$ & $270(85.2)$ \\
\hline Not disclosed & & $96(4.3)$ & $69(5.1)$ & $14(2.8)$ & $1(1.0)$ & $12(3.8)$ \\
\hline $\begin{array}{l}\text { Performed RT-PCR } \\
\text { for COVID-19 }\end{array}$ & $0.1 \%$ & $631(18.3)$ & $263(13.1)$ & $196(23.8)$ & $77(44.8)$ & $95(21.4)$ \\
\hline Positive & & 84 (13.3) & 35 (13.3) & $22(11.2)$ & $14(18.1)$ & $13(13.7)$ \\
\hline Negative & & 547 (86.7) & $228(86.7)$ & $174(88.8)$ & $63(81.8)$ & $82(86.3)$ \\
\hline
\end{tabular}

† ISCO: International Standard Classification of Occupation. ‡ PPE: Personal protective equipment.

Many participants reported symptoms compatible with COVID-19 infection. The presence of symptoms by serological status is presented on Appendix B.

\subsection{Local Prevention Measures and Epidemiology in Each Hospital}

The medico-surgical bed capacity ranged from 265 beds in Hospital 4 to 972 beds in Hospital 3. All but Hospital 4 had 12 to 18 ICU beds before the pandemic. Infection control teams and infectious disease specialists were available in all the participating hospitals before the pandemic. During the first wave, 1319 COVID-19 cases were admitted to the participating hospitals, ranging from 249 (Hospital 4) to 533 (Hospital 1). At the peak, COVID-19 cases were occupying $9.5 \%$ to $21.9 \%$ of the medico-surgical beds. Patients with COVID-19 were mostly hospitalized in dedicated units, with a ratio of 1 nurse per 7 to 10 beds. All hospitals had increased ICU bed capacity beyond 200\%. All-cause mortality among COVID-19 cases ranged from $6.5 \%$ to $14.9 \%$. Every hospital recommended systematic surgical mask-wearing, regardless of the patients' COVID-19 status. It was first supported for professionals with a patient-facing role, then extended to any healthcare worker. In Hospitals 1 and 3, it was even recommended before the pandemic, as part of the usual hospital-acquired flu prevention strategy. Because of shortages, Hospitals 1 and 2 increased the using time of surgical masks to $8 \mathrm{~h}$ instead of $4 \mathrm{~h}$. None of the hospitals faced shortages of disposable filter respiratory protection (N95/FFP2). Appendix C details the characteristics of the participating sites. 


\subsection{Prevalence of SARS-CoV-2 Infection}

The overall seroprevalence of SARS-CoV-2 infection was 5.0\% (CI 95, 4.3\% to 5.8\%). It varied by hospital, ranging from $3.3 \%$ (CI $95,2.5 \%$ to $4.1 \%$ ) to $10.4 \%$ (CI $95,7.7 \%$ to $13.6 \%)$.

\subsection{Factors Associated with an Increased Prevalence}

Figure 2 shows the seroprevalence of infection by type of occupation according to the ISCO. The type of occupation, according to the ISCO, was not associated with higher prevalence.

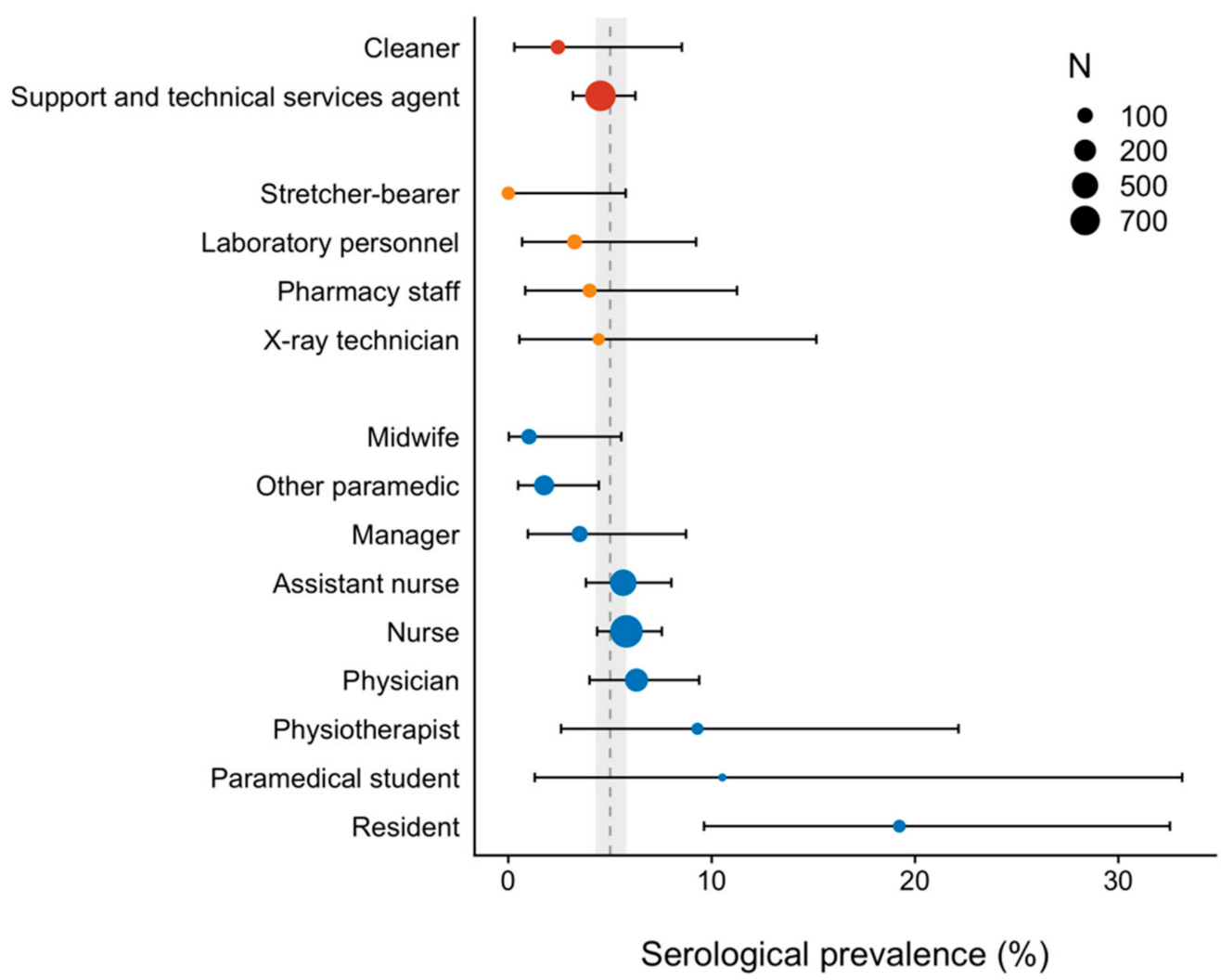

Figure 2. Seroprevalence of SARS-CoV-2 infection by type of occupation according to the ISCO. Health management and support personnel are presented in red, health associate professionals are yellow, and health professionals are blue. The size of the dots represents the number of subjects. The vertical dashed line is the estimated seroprevalence in the healthcare worker population with its $95 \%$ confidence interval (grey area).

Figure 3 shows the seroprevalence of infection according to healthcare workers' characteristics. Young professionals below 30 years old (aOR $=1.59$, (CI 95, 1.06 to 2.37)), including paramedical students and residents $(\mathrm{aOR}=3.38$, (CI 95, 1.62 to 7.05$)$ ), showed an increased rate of infection. The location of work, including emergency wards and COVID-19 units, was not associated with an increase in infections. 


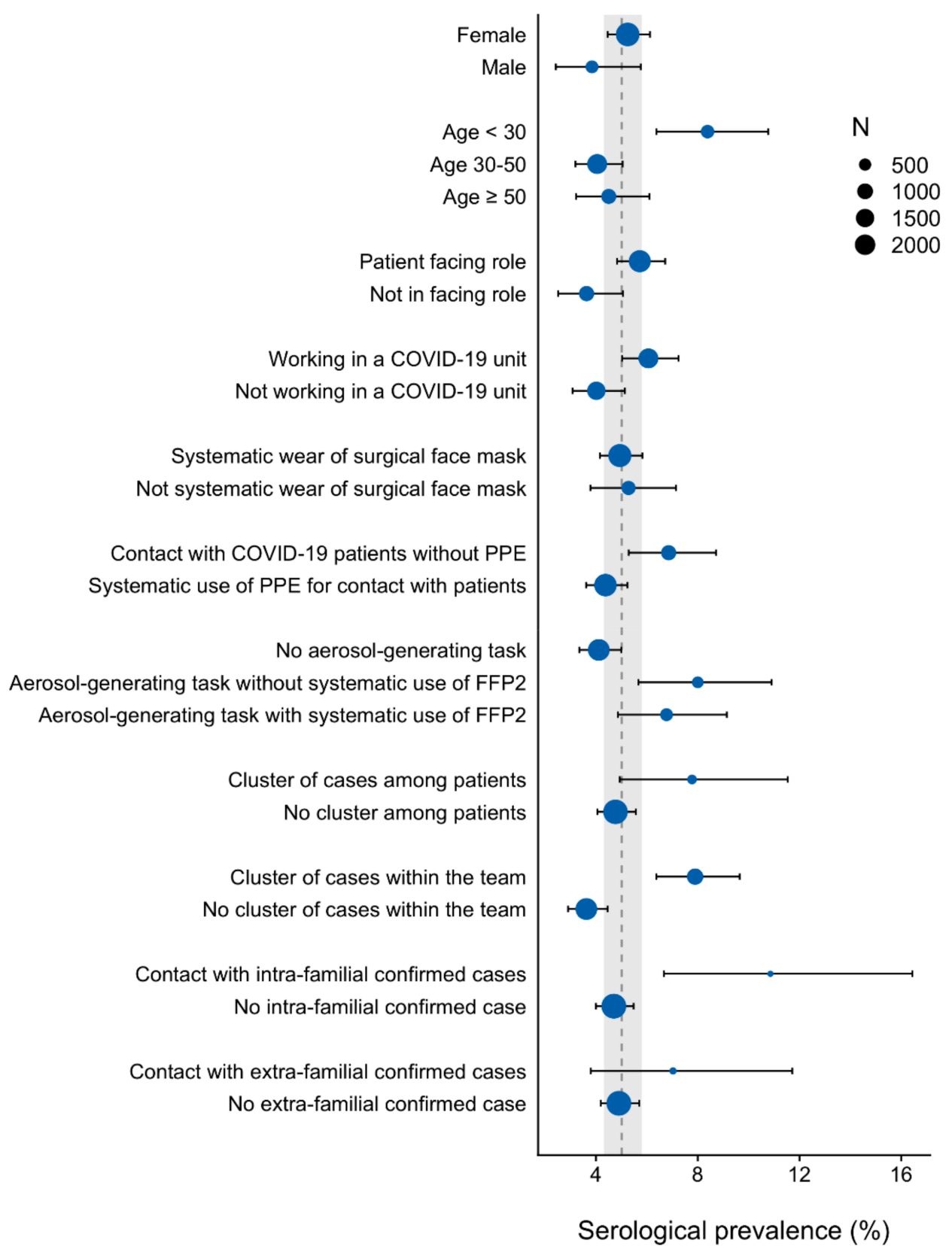

Figure 3. Seroprevalence of SARS-CoV-2 infection by characteristics of healthcare workers. The size of the dots represents the number of subjects. The vertical dashed line is the estimated seroprevalence in the healthcare worker population with its $95 \%$ confidence interval (grey area).

Table 2 summarizes the results of univariable and multivariable associations with seroprevalent infections. Staff members in patient-facing roles did not show an increased likelihood of infection. Healthcare workers reporting contact with COVID-19 patients without adequate protective equipment had a higher infection rate (aOR = 1.66, (CI 95, 1.12 to 2.44)). However, the systematic wearing of surgical face masks was not associated with decreased seroprevalence. For those who performed aerosol-generating procedures, the use of an N95/FFP2 mask did not reduce the rate of infection. Note that the wearing of an N95/FFP2 mask was not recommended for aerosol-generating tasks in patients without confirmed COVID-19. In addition, generalized screening of SARS-CoV-2 infection among any newly admitted patients was not performed during the study period. Healthcare workers exposed to clusters of COVID-19-infected colleagues (aOR = 1.77, (CI 95, 1.24 to 2.53)) or intra-familial COVID-19 relatives ( $\mathrm{aOR}=2.09,(\mathrm{CI} 95,1.15$ to 3.80) $)$ had a 
higher likelihood of infection, whereas healthcare workers with extra-familial exposure to COVID-19 cases did not show an increased rate of infection.

Table 2. Univariable and multivariable binomial logistic regression associations with SARS-CoV-2 infection among healthcare workers $(\mathrm{N}=3299)$.

\begin{tabular}{|c|c|c|c|c|c|c|}
\hline \multirow{2}{*}{ Variables } & \multicolumn{2}{|c|}{ Univariate } & \multicolumn{4}{|c|}{ Multivariate } \\
\hline & Odds Ratio & CI 95 & $p$-Value & $\begin{array}{c}\text { Adjusted Odds } \\
\text { Ratio }\end{array}$ & CI 95 & $p$-Value \\
\hline \multicolumn{7}{|l|}{$\begin{array}{c}\text { Age (ref. } 30 \text { to } \\
50 \text { years) }\end{array}$} \\
\hline$<30$ years & 2.17 & $(1.52-3.11)$ & $<0.001$ & 1.59 & $(1.06-2.37)$ & 0.024 \\
\hline$>50$ years & 1.12 & (0.75-1.66) & 0.581 & 1.28 & $(0.83-1.96)$ & 0.259 \\
\hline $\begin{array}{c}\text { Female (ref. } \\
\text { male) }\end{array}$ & 1.39 & $(0.88-2.19)$ & 0.161 & 1.55 & $(0.94-2.54)$ & 0.085 \\
\hline \multicolumn{7}{|l|}{$\begin{array}{l}\text { Profession, } \\
\text { according to } \\
\text { ISCO }{ }^{+} \\
\text {(ref. health }\end{array}$} \\
\hline \multicolumn{7}{|l|}{$\begin{array}{l}\text { management and } \\
\text { support } \\
\text { personnel) }\end{array}$} \\
\hline $\begin{array}{c}\text { Health } \\
\text { associate } \\
\text { professionals }\end{array}$ & 1.12 & $(0.70-1.79)$ & 0.632 & 0.87 & $(0.50-1.53)$ & 0.634 \\
\hline $\begin{array}{l}\text { Health } \\
\text { professionals }\end{array}$ & 1.27 & $(0.86-1.87)$ & 0.223 & 0.67 & $(0.39-1.16)$ & 0.157 \\
\hline $\begin{array}{l}\text { Paramedical } \\
\text { student or } \\
\text { resident (ref. not } \\
\text { a student) }\end{array}$ & 4.05 & $(2.13-7.69)$ & $<0.001$ & 3.38 & $(1.62-7.05)$ & 0.001 \\
\hline $\begin{array}{l}\text { Patient-facing } \\
\text { role (ref. not in } \\
\text { facing role) }\end{array}$ & 1.61 & (1.09-2.38) & 0.016 & 1.10 & $(0.65-1.87)$ & 0.712 \\
\hline $\begin{array}{l}\text { Working in } \\
\text { emergency } \\
\text { ward (ref. not in } \\
\text { emergency ward) }\end{array}$ & 1.51 & $(0.93-2.44)$ & 0.097 & 0.85 & $(0.49-1.49)$ & 0.571 \\
\hline Working in a & & & & & & \\
\hline $\begin{array}{l}\text { COVID-19 unit } \\
\text { (ref. not in }\end{array}$ & 1.54 & $(1.12-2.13)$ & 0.008 & 1.03 & $(0.67-1.58)$ & 0.899 \\
\hline $\begin{array}{l}\text { COVID-19 unit) } \\
\text { Contact with }\end{array}$ & & & & & & \\
\hline $\begin{array}{l}\text { COVID-19 } \\
\text { patients }\end{array}$ & & & & & & \\
\hline $\begin{array}{l}\text { without PPE } \ddagger \\
\text { (ref. systematic } \\
\text { use of PPE for } \\
\text { contact with } \\
\text { patients) }\end{array}$ & 2.37 & $(1.73-3.25)$ & $<0.001$ & 1.66 & $(1.12-2.44)$ & 0.011 \\
\hline $\begin{array}{c}\text { Systematic } \\
\text { wear of surgical } \\
\text { face mask } \\
\text { (ref. not } \\
\text { systematic) }\end{array}$ & 0.93 & $(0.65-1.34)$ & 0.706 & 0.71 & $(0.45-1.13)$ & 0.151 \\
\hline
\end{tabular}


Table 2. Cont.

\begin{tabular}{|c|c|c|c|c|c|c|}
\hline \multirow{2}{*}{ Variables } & \multicolumn{2}{|c|}{ Univariate } & \multicolumn{4}{|c|}{ Multivariate } \\
\hline & Odds Ratio & CI 95 & $p$-Value & $\begin{array}{c}\text { Adjusted Odds } \\
\text { Ratio }\end{array}$ & CI 95 & $p$-Value \\
\hline $\begin{array}{c}\text { Aerosol- } \\
\text { generating task } \\
\text { (ref. not } \\
\text { concerned) }\end{array}$ & & & & & & \\
\hline $\begin{array}{c}\text { Systematic use } \\
\text { of FFP2 }\end{array}$ & 1.70 & $(1.15-2.49)$ & 0.007 & 1.74 & $(1.06-2.85)$ & 0.028 \\
\hline $\begin{array}{c}\text { Without } \\
\text { systematic use } \\
\text { of FFP2 }\end{array}$ & 2.03 & $(1.36-3.02)$ & $<0.001$ & 1.81 & $(1.09-3.01)$ & 0.021 \\
\hline $\begin{array}{l}\text { Cluster of cases } \\
\text { among patients } \\
\text { (ref. not) }\end{array}$ & 1.69 & $(1.06-2.68)$ & 0.028 & 1.31 & $(0.79-2.19)$ & 0.299 \\
\hline $\begin{array}{l}\text { Cluster of cases } \\
\text { within the team } \\
\text { (ref. not) }\end{array}$ & 2.28 & $(1.68-3.11)$ & $<0.001$ & 1.77 & $(1.24-2.53)$ & 0.002 \\
\hline $\begin{array}{c}\text { Working } \\
\text { remotely at } \\
\text { full-time (ref. } \\
\text { not) }\end{array}$ & 1.41 & $(0.51-3.95)$ & 0.509 & 2.39 & $(0.79-7.19)$ & 0.121 \\
\hline $\begin{array}{c}\text { Intra-familial } \\
\text { confirmed cases } \\
(\text { ref. not })\end{array}$ & 2.47 & $(1.49-4.09)$ & $<0.001$ & 2.09 & $(1.15-3.80)$ & 0.015 \\
\hline $\begin{array}{c}\text { Extra-familial } \\
\text { confirmed cases } \\
(\text { ref. not })\end{array}$ & 1.47 & $(0.82-2.64)$ & 0.199 & 0.81 & $(0.40-1.64)$ & 0.555 \\
\hline
\end{tabular}

† ISCO: International Standard Classification of Occupation. ‡ PPE: Personal protective equipment.

\section{Discussion}

The seroprevalence of SARS-CoV-2 infection among healthcare workers of the French Alps was 5.0\% (CI 95, 4.3\% to 5.8\%) after the first wave of the pandemic. It was higher in young professionals (including students), in those performing an aerosol-generating procedure, those exposed to COVID-19 cases without adequate uptake of protective equipment, and those reporting contact with clusters of infected colleagues and intra-familial cases.

We showed a relatively low prevalence of infection $(5.0 \%)$ after the first wave. This is in the $3.4 \%$ to $11.2 \%$ range described in other European surveys [10-14]. We estimated that the prevalence (inverse variance method with random effect) among French healthcare workers was $12.0 \%$ (CI $95,7.0 \%$ to $19.0 \%$ ), varying by the sampling method, and ranging from $7.0 \%$ when considering any healthcare workers to $12 \%$ among frontline caregivers, and $31.0 \%$ among symptomatic health professionals (Appendix D) [3,5,15-18]. Such a variation in estimation highlights the need to identify subgroups at higher risk of infection. In our multi-centric study, we estimated the effect of individual uptake of protective equipment and intra-/extra-professional exposure to the virus on the infection rate.

We found the lowest prevalence in health professional management support (4.3\%), which served as a proxy for the general population. Over the same timeframe, Le Vu et al. reported a $4.4 \%$ prevalence within the surveyed area's general population [9]. Other studies compared the prevalence among healthcare workers to the general population without a proper internal control group. They showed a higher likelihood of infection among healthcare workers but did not report on the availability and type of protective equipment used, its uptake by healthcare workers, nor organizational characteristics at the hospital level $[10,19,20]$. In our study, none of the participating hospitals faced a real shortage of protective equipment. The organizational and epidemiological characteristics 
of the hospitals were fairly homogeneous, as were the implementation of local guidelines for the systematic wearing of a facemask by healthcare workers.

Some studies have reported that males are at a higher risk of infection than females $[13,17]$. Females represented $83.4 \%$ of our sample and this may have contributed to a lower seroprevalence. However, the administrative data describing the workforce of the participating sites showed the same sex ratio. This low prevalence is likely to reflect a low circulation of the virus within the surveyed area, rather than a biased selection towards women. Only a third of professionals underwent serology testing, of which we enrolled three-quarters. A sampling bias can thereby exist for professionals previously infected, resulting in an underestimation of prevalence.

In our study, professionals who performed aerosol-generating procedures and who were exposed to COVID-19 patients without appropriate protective equipment were at higher risk of infection, unlike those facing patients (infected or not) or working in a COVID19 unit. This contrasts with previous reports $[1,10,14,20-23]$. This suggests that a lack of compliance with hygiene measures drives the risk of infection rather than the location of practice. Indeed, at the time of the study, N95/FFP2s were used for aerosol-generating tasks in COVID-19 patients only (oral intubation, aerosolized therapy, high-flow oxygen, etc.). A French survey among healthcare workers showed a lower use of protective equipment in non-COVID-19 units ( $0 \%$ to $51 \%$ ) than in high-risk areas (56\% to $87 \%$ ) [24]. These results stressed the implementation of reinforced preventive measures in our hospitals, including the systematic use of N95/FFP2 for any aerosol-generating task. Since November 2020, a generalized screening of COVID-19 infection by RT-PCR at hospital admission has also been implemented.

The professional category was not associated with an increased prevalence of infection, but young professionals $(8.3 \%)$, including paramedic students and residents, had a higher infection rate (16.9\%) compared to others (4.0\% to $4.7 \%)$. A Danish study found similar results because of a hotspot identified among medical students attending a social gathering at a university club [25]. Hygiene training dedicated to students should be promoted.

Finally, in our study, the strongest associations with SARS-CoV-2 infection were not related to close contact with patients. Indeed, students and workers in contact with COVID19 cases among their colleagues or relatives had the highest infection rate. In the literature, few articles have highlighted that cross-transmission between healthcare workers can occur $[11,14]$. During the first wave, most infected health professionals continued working unless being severely symptomatic. On February 16, 2021, the French Ministry of Health decided to ban any infected professional from work. Our results thereby support the eviction of infected personnel from the hospital to prevent cross-transmission between staff members. Intra-familial exposure was already shown to drive infections, but little can be done to limit this risk $[14,22]$.

Our study was limited by the six-month lag between the first wave peak and the end of serological sampling. Some studies showed an antibody titer decrease three to six months after infection in more than half of the infected people [26]. Despite the high performance of serological kits used, this may have contributed to a low seroprevalence. Second, inclusions were not exhaustive, and sampling bias could have occurred. Third, the cross-sectional design did not allow for collecting repeated data or for drafting causalities. Nevertheless, we investigated the uptake of protective equipment and hygiene measures at an individual level. Even if measurement biases are likely with our design, the lack of shortage in protective equipment over the studied period reinforces the confidence in the interpretation of associations. We also used health management support professionals as an internal control group, allowing us to compare our results with the general population.

\section{Conclusions}

In a general population of healthcare workers with sustained availability of personal protective equipment, the rate of SARS-CoV-2 infection was low and comparable to that of the general population. Young professionals are particularly at risk and may benefit from 
dedicated hygiene training. Cross-transmission between healthcare workers is a real threat to care continuation. It justifies the systematic eviction of infected personnel and stresses the need for interventions to increase vaccination coverage among any healthcare workers.

Author Contributions: Conceptualization: M.N., S.N. and V.V.; methodology: T.D.; funding acquisition: T.D., M.N. and V.V.; project administration: T.D., M.N. and V.V.; investigation: A.B., B.C., A.R., A.V. and C.W.; data curation: T.D. and A.M.; formal analysis: A.M.; supervision: T.D.; original draft preparation: T.D., A.M., M.N. and V.V.; review and editing: A.B., B.C., T.D., A.M., M.N., A.R., A.V., V.V. and C.W. All authors have read and agreed to the published version of the manuscript.

Funding: The study was funded by a grant from the Alpine Arc area, obtained in 2020.

Institutional Review Board Statement: The serotesting was voluntary, free of cost, and provided without monetary incentives. Antibody testing was also provided to healthcare workers not willing to participate in the study. This multi-centric observational study was registered with the French authorities under the number MR004-2205982 (Annecy Genevois hospital). The data collection process was in line with the European General Data Protection Regulation. This study was approved by the Institutional Review Board of the French Infectious Disease Society (CER-MIT N IRB00011642).

Informed Consent Statement: Informed consent was obtained from all healthcare workers involved in the study.

Data Availability Statement: The authors confirm that the data supporting the findings of this study are available within the article (and/or) the Appendix A, Appendix B, Appendix C, and Appendix D.

Acknowledgments: We thank all the personnel for their participation in the study. We thank the laboratory technician, the biologists, and the infection control and occupational medicine teams of every participating site. We also thank the research assistants of every participating hospital for data collection and data quality control. We thank Gabriel Macheda for his participation in the protocol and questionnaires' redaction. We also thank the hospital directors for allowing data collection and providing access to information about their personnel.

Conflicts of Interest: The authors declare no conflict of interest.

\title{
Appendix A
}

Self-Questionnaire Administered to Healthcare Workers

Date of birth: MM/YYYY

Sex: $M / F$

Weight: kgs

Height: $\mathrm{cm}$

Date of survey completion: DD/MM/YYYY

PROFESSIONNAL ACTIVITY

(1) What is your occupation (unique choice)?

\author{
Assistant nurse \\ Service agent \\ Support services agent (administrative staff, catering, clinical research, etc.) \\ Stretcher bearer \\ Nurse manager \\ Student (assistant nurse student, nurse student, etc.) \\ Nurse \\ Medical student \\ Physiotherapist \\ Medical doctor/specialist physician \\ Pharmacist \\ Laboratory staff \\ Pharmaceutical technicians and assistant \\ Clinical research staff
}


Technical services

Other paramedics (social assistant, psychologist, etc.)

Midwife

Other (specify):

(2) Usual affectation (before COVID-19 period) (unique choice)?

Medicine (geriatric included)

Surgery

Anesthesia

Emergency

Gynecology

Pediatrics

Critical care

Pharmacy

Technical services

Administrative units

Other (specify):

(3) Usual working time:

Before COVID-19 pandemic (unique choice)?

$100 \%$

$80-99 \%$

$50-79 \%$

$<50 \%$

During COVID-19 pandemic (unique choice)?

$100 \%$

$80-99 \%$

$50-79 \%$

$<50 \%$

(4) Did you work remotely during lockdown (unique choice)?

Never

Sometimes

Every day

(5) During lockdown, did you work at least $12 \mathrm{~h}$ physically per day (unique choice)?

Never

Sometimes

Often

Always

(6) According to you, between February and May 2020, did you work longer than your usual working time?

Yes

No

COVID-19 PREVENTION MESURES

(7) Did you receive hygiene training since your recruitment?

Yes

No

If yes, please specify when the training was:

In the past 12 months

Between 1 and 4 years ago

More than 5 years ago 
(8) Since February 2020, did you receive specific COVID-19 hygiene information?

Yes

No

If yes, which items were discussed (multiple choice)?

- Surgical mask use

Particle filter disposable system (FFP2) use

Hands hygiene

Professional scrubs

Patient orientation

Case definition and screening

(9) Complete the following questions only if you have a patient-facing role:

Are you aware of the WHO guidelines on hand hygiene in health care?

Yes

No

If yes, please specify (unique choice):

One moment out of five

Two moments out of five

Three moments out of five

Four moments out of five

Five moments out of five

(10) During the COVID-19 period, did you wear a surgical mask at work (unique choice)?

Never

Sometimes

Often

Always

(11) During the COVID-19 period, were you exposed to aerosol-generating procedures (nasopharyngeal test, intubation, etc.) for COVID-19 or non-COVID-19 patients?

Yes

No

If yes, did you systematically use a particle filter disposable system (N95/FFP2) (unique choice)?

Never

Sometimes

Often

Always

If not, why didn't you wear adapted protective equipment (unique choice)?

Shortage

Emergency

Forgot

Other (specify)

SYMPTOMS

(12) During the past six months, have you had one or more symptoms?

Yes

No

If yes, specify (multiple choice):

Fever

Sore throat

Cough

Nasal discharge

Dyspnea 
Chills

Vomiting

Nausea

Diarrhea

Headache

Skin rash

Conjunctivitis

Muscle pain/aches

Loss of appetite

Loss of smell (anosmia) or taste

Nose bleeds

Tired

Convulsions

Altered consciousness

Other neurological signs

Other symptoms

If you have presented one or more symptoms, please indicate the overall intensity of your symptoms:

Please indicate the intensity of your symptoms from 0 (no symptoms) to 10 (most intense symptoms)

If you have had one or more symptoms, please indicate when they appeared, compared to today's date (unique choice):

In the last 14 days

Between 15 and 30 days ago

More than 30 days ago

If you have presented one or more symptoms, please indicate whether any persist to this day:

Yes

No

Overall intensity of current symptoms:

Please indicate the intensity of your symptoms from 0 (no symptoms) to 10 (most intense symptoms)

(13) Have you ever performed a PCR test for SARS-CoV-2?

Yes

No

If yes, please indicate the test result (unique choice):

Positive

Negative

Undetermined

If not, specify the reason (unique choice):

No indication

Not available

Unsuitable practical method (waiting period, location, hours, etc.)

Fear of test

\section{RISK CONTACT AT WORK}

(14) In your professional activity during the past 6 months, have you had direct contact (s) with COVID-19 or non-COVID-19 patients within one meter (unique choice)?

Never

Sometimes

Often

Every day that I was in office

(15) Have you worked in a COVID-19 unit (unique choice)?: 
Never

Sometimes

Often

Every day that I was in office

(16) Have you been in direct contact with a confirmed COVID-19 patient, without adequate protection (unique choice)?

Never

Sometimes

Often

Every day that I was in office

(17) Have there been any professional clusters of COVID-19 infection in your unit?

Yes

No

(18) If your activity takes place in a non-COVID-19 unit, have there been any clusters of COVID-19 infection in patients/residents?

Yes

No

(19) In your professional activity, have you complied with physical distancing when not wearing a facemask (i.e., during breaks) (unique choice):

Never

Sometimes

Often

Every day that I was in office

(20) During your professional activity, have you been in contact (without suitable protective measures) with a work colleague confirmed to have COVID-19 (unique choice)?

Never

Sometimes

Often

Every day that I was in office

EXTRA-PROFESSIONAL RISK CONTACT

(21) At home, you live (unique choice):

Alone

Two people (including you)

3 people (including you)

4 or more people (including you)

(22) In your household, there are children $<18$ years old (unique choice):

Yes

No

If yes, over the past 6 months, have your children been in community care? (School, nursery, daycare, etc.) (unique choice):

Never

Sometimes

Often

Every day that I was in office

(23) In your household, there are other caregivers than you:

Yes

No 
(24) In the past 6 months, have you been in contact (without adequate protection) with a confirmed case of COVID-19 in your family:

Yes

No

I don't know

(25) In the past 6 months, have you been in contact (without adequate protection) with a confirmed case of COVID-19 in extra-family private life:

Yes

No

I don't know

(26) In the past 6 months, have you used public transport (unique choice)?

Never

Sometimes

Often

Systematically

(27) In the past 6 months, have you been in contact with no protective measures with a sick person (respiratory symptoms, such as cough, dyspnea, fever)?

Yes

No

I don't know 


\section{Appendix B}

Table A1. Symptoms Reported by SARS CoV-2 Seropositive and Seronegative Professionals.

\begin{tabular}{|c|c|c|c|c|c|}
\hline \multirow{3}{*}{$\begin{array}{l}\text { Characteristics } \\
\text { and Timing of } \\
\text { Reported } \\
\text { Symptoms }\end{array}$} & \multirow{3}{*}{ Missing (\%) } & \multirow{2}{*}{$\begin{array}{l}\text { Overall } \\
\mathrm{N}=3454\end{array}$} & \multirow{2}{*}{$\begin{array}{l}\text { Negative } \\
\text { Serology }\end{array}$} & \multirow{2}{*}{$\begin{array}{l}\text { Positive Serology } \\
\qquad \mathbf{N}=\mathbf{1 7 3}\end{array}$} & \multirow[t]{2}{*}{$p$-Value } \\
\hline & & & & & \\
\hline & & $N(\%)$ & $N(\%)$ & $N(\%)$ & \\
\hline \multicolumn{6}{|l|}{ Reporting symptoms } \\
\hline $\begin{array}{l}\text { compatible with } \\
\text { COVID-19 }\end{array}$ & $0.0 \%$ & $2254(65.3)$ & $2098(63.9)$ & $156(90.2)$ & $<0.001$ \\
\hline Fever & $1.7 \%$ & 589 (17.3) & $508(15.8)$ & $81(47.1)$ & $<0.001$ \\
\hline Sore throat & $1.7 \%$ & $414(12.2)$ & 364 (11.3) & $50(29.1)$ & $<0.001$ \\
\hline Cough & $1.7 \%$ & $1037(30.5)$ & $973(30.2)$ & $64(37.2)$ & 0.062 \\
\hline Nasal discharge & $1.7 \%$ & $963(28.3)$ & $879(27.3)$ & $84(48.8)$ & $<0.001$ \\
\hline Dyspnea & $1.7 \%$ & $1155(34.0)$ & $1074(33.3)$ & $81(47.1)$ & $<0.001$ \\
\hline Chills & $1.7 \%$ & $424(12.5)$ & $371(11.5)$ & $53(30.8)$ & $<0.001$ \\
\hline $\begin{array}{l}\text { Digestive } \\
\text { symptoms }\end{array}$ & $1.7 \%$ & $692(20.4)$ & $644(20.0)$ & 48 (27.9) & 0.015 \\
\hline Vomiting & $1.7 \%$ & $111(3.3)$ & $105(3.3)$ & $6(3.5)$ & 1.000 \\
\hline Nausea & $1.7 \%$ & $332(9.8)$ & $310(9.6)$ & $22(12.8)$ & 0.216 \\
\hline Diarrhea & $1.7 \%$ & $513(15.1)$ & $472(14.6)$ & $41(23.8)$ & 0.002 \\
\hline Headache & $1.7 \%$ & $1325(39.0)$ & $1226(38.0)$ & $99(57.6)$ & $<0.001$ \\
\hline Skin rash & $1.7 \%$ & $114(3.4)$ & $102(3.2)$ & $12(7.0)$ & 0.013 \\
\hline Conjunctivitis & $1.7 \%$ & $113(3.3)$ & $106(3.3)$ & $7(4.1)$ & 0.734 \\
\hline Muscle pain/aches & $1.7 \%$ & $650(19.1)$ & $575(17.8)$ & $75(43.6)$ & $<0.001$ \\
\hline Loss of appetite & $1.7 \%$ & $191(5.6)$ & $155(4.8)$ & $36(20.9)$ & $<0.001$ \\
\hline $\begin{array}{c}\text { Loss of smell } \\
\text { (anosmia) or taste }\end{array}$ & $1.7 \%$ & $149(4.4)$ & $77(2.4)$ & $72(41.9)$ & $<0.001$ \\
\hline Nose bleeds & $1.7 \%$ & $83(2.4)$ & $74(2.3)$ & $9(5.2)$ & 0.029 \\
\hline Tired & $1.7 \%$ & $1379(40.6)$ & $1269(39.3)$ & $110(64.0)$ & $<0.001$ \\
\hline Neurological signs & $1.7 \%$ & $36(1.1)$ & $32(1.0)$ & $4(2.3)$ & 0.200 \\
\hline Convulsions & $1.7 \%$ & $10(0.3)$ & $10(0.3)$ & $0(0.0)$ & 0.993 \\
\hline $\begin{array}{c}\text { Altered } \\
\text { consciousness }\end{array}$ & $1.7 \%$ & $7(0.2)$ & $6(0.2)$ & $1(0.6)$ & 0.802 \\
\hline $\begin{array}{l}\text { Other neurological } \\
\text { signs }\end{array}$ & $1.7 \%$ & $19(0.6)$ & $16(0.5)$ & $3(1.7)$ & 0.107 \\
\hline $\begin{array}{l}\text { Other symptoms } \\
\text { Time between }\end{array}$ & $1.7 \%$ & $67(2.0)$ & $58(1.8)$ & $9(5.2)$ & 0.004 \\
\hline $\begin{array}{l}\text { symptoms and } \\
\text { serological screening }\end{array}$ & $34.8 \%$ & & & & 0.014 \\
\hline$\leq 14$ days & & $104(4.6)$ & $102(4.9)$ & $2(1.3)$ & \\
\hline $1 \overline{5}-29$ days & & $194(8.6)$ & $188(9.0)$ & $6(3.8)$ & \\
\hline$\geq 30$ days & & $1857(82.5)$ & $1714(81.8)$ & $143(91.7)$ & \\
\hline Not disclosed & & $96(4.3)$ & $91(4.3)$ & $5(3.2)$ & \\
\hline $\begin{array}{l}\text { Performed RT-PCR } \\
\text { for COVID-19 }\end{array}$ & $0.1 \%$ & $631(18.3)$ & $544(16.6)$ & 87 (50.6) & $<0.001$ \\
\hline Positive & $0.1 \%$ & $84(2.4)$ & $19(0.6)$ & $65(37.8)$ & \\
\hline Negative & & 547 (15.9) & $525(16.0)$ & $22(12.8)$ & \\
\hline
\end{tabular}




\section{Appendix C}

Table A2. Characteristics of Participating Hospitals.

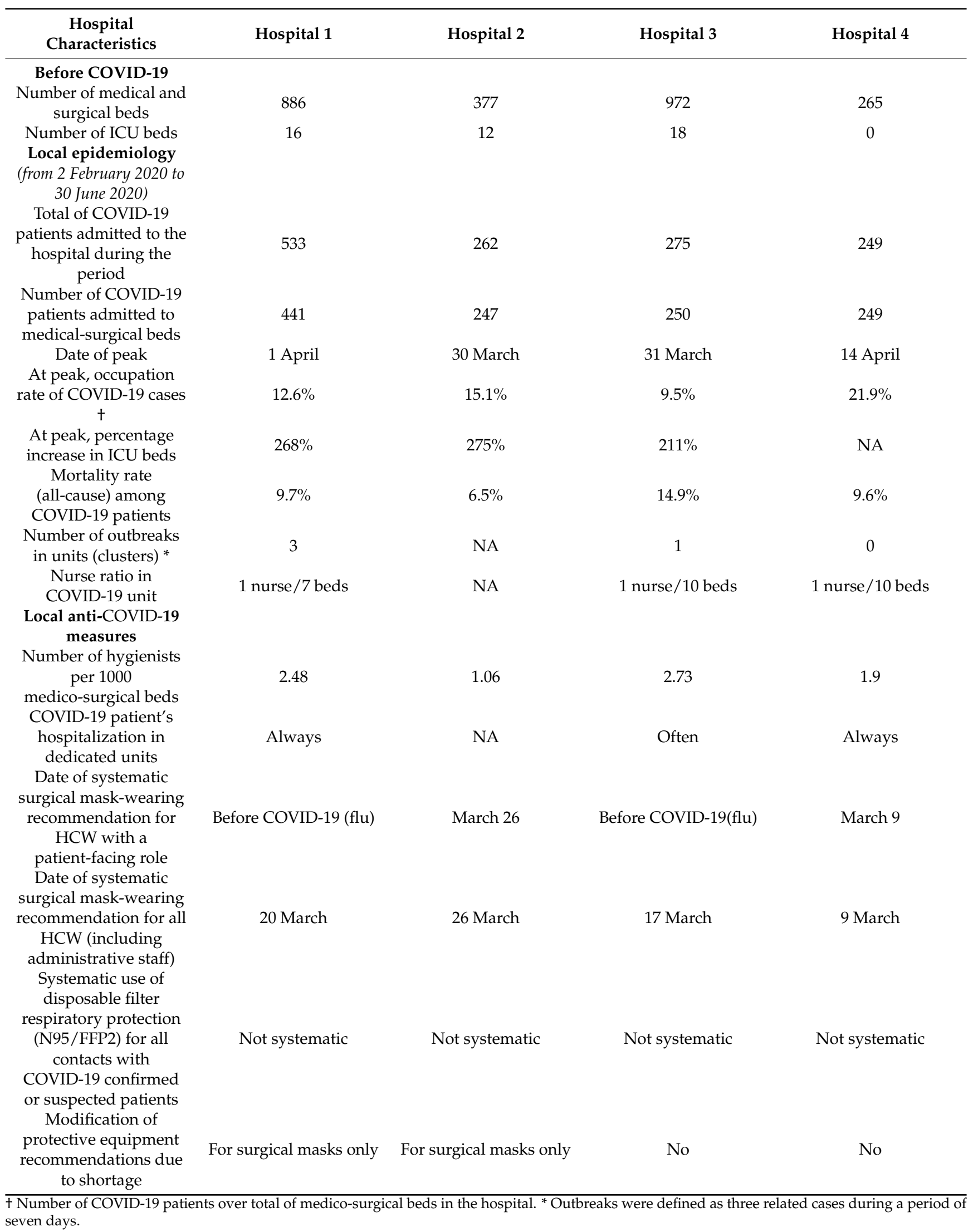




\section{Appendix D}

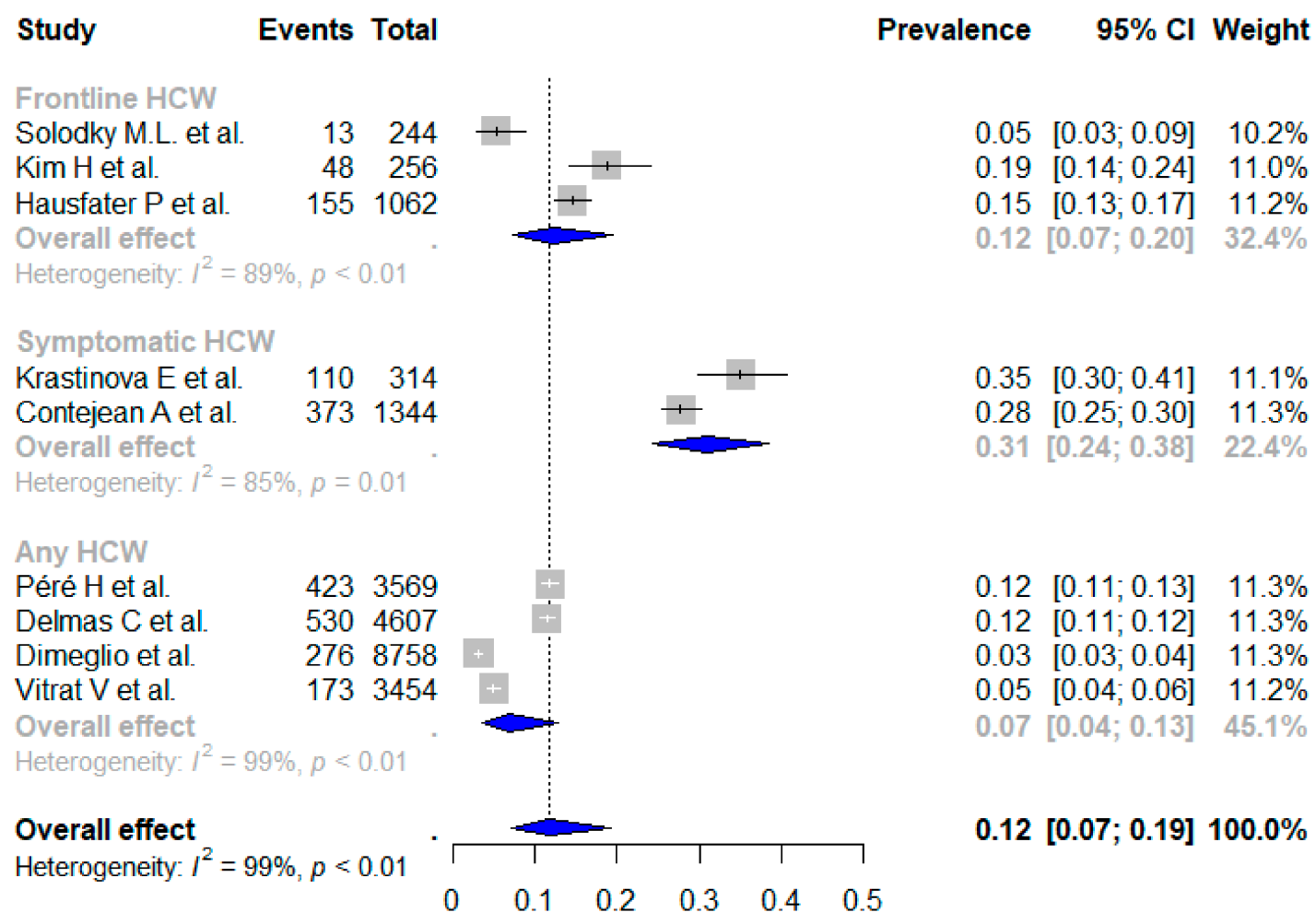

Figure A1. Pooled Prevalence of SARS-CoV-2 Infection among French Healthcare Workers.

We estimated the pooled prevalence using the inverse variance method with random effect ('meta' package).

\section{References}

1. Shah, A.S.V.; Wood, R.; Gribben, C.; Caldwell, D.; Bishop, J.; Weir, A.; Kennedy, S.; Reid, M.; Smith-Palmer, A.; Goldberg, D.; et al. Risk of hospital admission with coronavirus disease 2019 in healthcare workers and their households: Nationwide linkage cohort study. BMJ 2020, 371, m3582. [CrossRef]

2. Martin, C.; Montesinos, I.; Dauby, N.; Gilles, C.; Dahma, H.; Van Den Wijngaert, S.; De Wit, S.; Delforge, M.; Clumeck, N.; Vandenberg, O. Dynamics of SARS-CoV-2 RT-PCR positivity and seroprevalence among high-risk healthcare workers and hospital staff. J. Hosp. Infect. 2020, 106, 102-106. [CrossRef] [PubMed]

3. Solodky, M.L.; Galvez, C.; Russias, B.; Detourbet, P.; N’Guyen-Bonin, V.; Herr, A.-L.; Zrounba, P.; Blay, J.-Y. Lower detection rates of SARS-COV2 antibodies in cancer patients versus health care workers after symptomatic COVID-19. Ann. Oncol. 2020, 31, 1087-1088. [CrossRef] [PubMed]

4. Guery, R.; Delaye, C.; Brule, N.; Nael, V.; Castain, L.; Raffi, F.; De Decker, L. Limited effectiveness of systematic screening by nasopharyngeal RT-PCR of medicalized nursing home staff after a first case of COVID-19 in a resident. Med. Mal. Infect. 2020, 50, 748-750. [CrossRef] [PubMed]

5. Contejean, A.; Leporrier, J.; Canouï, E.; Alby-Laurent, F.; Lafont, E.; Beaudeau, L.; Parize, P.; Lecieux, F.; Greffet, A.; Chéron, G.; et al. Comparing dynamics and determinants of SARS-CoV-2 transmissions among health care workers of adult and pediatric settings in central Paris. Clin. Infect. Dis. 2020. [CrossRef]

6. Self, W.H.; Tenforde, M.W.; Stubblefield, W.B.; Feldstein, L.R.; Steingrub, J.S.; Shapiro, N.I.; Ginde, A.A.; Prekker, M.E.; Brown, S.M.; Peltan, I.D.; et al. Seroprevalence of SARS-CoV-2 Among Frontline Health Care Personnel in a Multistate Hospital Network-13 Academic Medical Centers, April-June 2020. MMWR Morb. Mortal. Wkly. Rep. 2020, 69, 1221-1226. [CrossRef]

7. Food and Drug Administration. EUA Authorized Serology Test Performance; FDA: Washingtown, DC, USA, 2021.

8. International Standard Classifications of Occupations (ISCO-08). Available online: https://score.tools.who.int/tools/optimizehealth-service-data/tool/international-standard-classifications-of-occupations-isco-08-45/ (accessed on 16 March 2021).

9. Le Vu, S.; Jones, G.; Anna, F.; Rose, T.; Richard, J.-B.; Bernard-Stoecklin, S.; Goyard, S.; Demeret, C.; Helynck, O.; Escriou, N.; et al. Prevalence of SARS-CoV-2 antibodies in France: Results from nationwide serological surveillance. Nat. Commun. 2021, $12,3025$. [CrossRef] 
10. Jespersen, S.; Mikkelsen, S.; Greve, T.; Kaspersen, K.A.; Tolstrup, M.; Boldsen, J.K.; Redder, J.D.; Nielsen, K.; Abildgaard, A.M.; Kolstad, H.A.; et al. Severe Acute Respiratory Syndrome Coronavirus 2 Seroprevalence Survey Among 17971 Healthcare and Administrative Personnel at Hospitals, Prehospital Services, and Specialist Practitioners in the Central Denmark Region. Clin. Infect. Dis. 2020. [CrossRef]

11. Steensels, D.; Oris, E.; Coninx, L.; Nuyens, D.; Delforge, M.-L.; Vermeersch, P.; Heylen, L. Hospital-Wide SARS-CoV-2 Antibody Screening in 3056 Staff in a Tertiary Center in Belgium. JAMA 2020, 324, 195. [CrossRef]

12. Plebani, M.; Padoan, A.; Fedeli, U.; Schievano, E.; Vecchiato, E.; Lippi, G.; Lo Cascio, G.; Porru, S.; Palù, G. SARS-CoV-2 serosurvey in health care workers of the Veneto Region. Clin. Chem. Lab. Med. (CCLM) 2020. [CrossRef]

13. Lidström, A.-K.; Sund, F.; Albinsson, B.; Lindbäck, J.; Westman, G. Work at inpatient care units is associated with an increased risk of SARS-CoV-2 infection; a cross-sectional study of 8679 healthcare workers in Sweden. Ups. J. Med. Sci. 2020, 125, 305-310. [CrossRef] [PubMed]

14. Eyre, D.W.; Lumley, S.F.; O’Donnell, D.; Campbell, M.; Sims, E.; Lawson, E.; Warren, F.; James, T.; Cox, S.; Howarth, A.; et al. Differential occupational risks to healthcare workers from SARS-CoV-2 observed during a prospective observational study. Elife 2020, 9. [CrossRef] [PubMed]

15. Delmas, C.; Plu-Bureau, G.; Canouï, E.; Mouthon, L.; Meritet, J.-F. Clinical characteristics and persistence of severe acute respiratory coronavirus virus 2 (SARS-CoV-2) IgG antibodies in 4607 French healthcare workers: Comparison with European countries. Infect. Control Hosp. Epidemiol. 2020, 1-2. [CrossRef]

16. Dimeglio, C.; Herin, F.; Miedougé, M.; Cambus, J.-P.; Abravanel, F.; Mansuy, J.-M.; Soulat, J.-M.; Izopet, J. Screening for SARSCoV-2 antibodies among healthcare workers in a university hospital in southern France. J. Infect. 2021, 82, e29-e32. [CrossRef] [PubMed]

17. Péré, H.; Wack, M.; Védie, B.; Demory Guinet, N.; Kassis Chikani, N.; Janot, L.; Bélec, L.; Veyer, D. Sequential SARS-CoV-2 IgG assays as confirmatory strategy to confirm equivocal results: Hospital-wide antibody screening in 3569 staff health care workers in Paris. J. Clin. Virol. 2020, 132, 104617. [CrossRef] [PubMed]

18. Hausfater, P.; Boutolleau, D.; Lacombe, K.; Beurton, A.; Dumont, M.; Constantin, J.-M.; Ghosn, J.; Combes, A.; Cury, N.; Guedj, R.; et al. Cumulative incidence of SARS-CoV-2 infection and associated risk factors among frontline health care workers in Paris, France: The SEROCOV prospective cohort study. medRxiv 2021. [CrossRef]

19. Shields, A.; Faustini, S.E.; Perez-Toledo, M.; Jossi, S.; Aldera, E.; Allen, J.D.; Al-Taei, S.; Backhouse, C.; Bosworth, A.; Dunbar, L.A.; et al. SARS-CoV-2 seroprevalence and asymptomatic viral carriage in healthcare workers: A cross-sectional study. Thorax 2020, 75, 1089-1094. [CrossRef]

20. Rudberg, A.-S.; Havervall, S.; Månberg, A.; Jernbom Falk, A.; Aguilera, K.; Ng, H.; Gabrielsson, L.; Salomonsson, A.-C.; Hanke, L.; Murrell, B.; et al. SARS-CoV-2 exposure, symptoms and seroprevalence in healthcare workers in Sweden. Nat. Commun. 2020, 11. [CrossRef]

21. Sims, M.D.; Maine, G.N.; Childers, K.L.; Podolsky, R.H.; Voss, D.R.; Berkiw-Scenna, N.; Oh, J.; Heinrich, K.E.; Keil, H.; Kennedy, R.H.; et al. COVID-19 seropositivity and asymptomatic rates in healthcare workers are associated with job function and masking. Clin. Infect. Dis. 2020. [CrossRef]

22. Piccoli, L.; Ferrari, P.; Piumatti, G.; Jovic, S.; Rodriguez, B.F.; Mele, F.; Giacchetto-Sasselli, I.; Terrot, T.; Silacci-Fregni, C.; Cameroni, E.; et al. Risk assessment and seroprevalence of SARS-CoV-2 infection in healthcare workers of COVID-19 and non-COVID-19 hospitals in Southern Switzerland. Lancet Reg. Health-Eur. 2021, 1, 100013. [CrossRef]

23. Moscola, J.; Sembajwe, G.; Jarrett, M.; Farber, B.; Chang, T.; McGinn, T.; Davidson, K.W. Northwell Health COVID-19 Research Consortium Prevalence of SARS-CoV-2 Antibodies in Health Care Personnel in the New York City Area. JAMA 2020, $324,893$. [CrossRef]

24. Olivier, C.; Brunet, J.; Bouvet, E.; Abiteboul, D.; Lolom, I.; Pellissier, G.; Delaroque-Astagneau, E.; Rouveix, E. Context of Healthcare Workers contamination during the first SARS-CoV-2 epidemic wave in France. Bull. Epidemiol. Hebd. 2020, 35, 690-695.

25. Iversen, K.; Bundgaard, H.; Hasselbalch, R.B.; Kristensen, J.H.; Nielsen, P.B.; Pries-Heje, M.; Knudsen, A.D.; Christensen, C.E.; Fogh, K.; Norsk, J.B.; et al. Risk of COVID-19 in health-care workers in Denmark: An observational cohort study. Lancet Infect. Dis. 2020, 20, 1401-1408. [CrossRef]

26. Post, N.; Eddy, D.; Huntley, C.; van Schalkwyk, M.C.I.; Shrotri, M.; Leeman, D.; Rigby, S.; Williams, S.V.; Bermingham, W.H.; Kellam, P.; et al. Antibody response to SARS-CoV-2 infection in humans: A systematic review. PLoS ONE 2020, 15, e0244126. [CrossRef] [PubMed] 